\title{
IDIOSINKRASI ISTRI DALAM MENCARIKAN PASANGAN BARU BAGI SUAMI PERSPEKTIF GENDER
}

\author{
Hawa' Hidayatul Hikmiyah \\ Universitas Islam Negeri Maulana Malik Ibrahim Malang. E-mail: \\ hawahidayatulhikmiyah@gmail.com
}

\begin{abstract}
Idiosink rasi of wife in finding a new wife for her husband is considered as another behavior of most wives in general. Every wife will not want to be polygamy by her busband, but in contrast to the behavior of the wives in the polygamy community is destiny, the majority of wives in the community are competing in achieving Allah's blessing by finding a new wife for her husband. The wife's behavior is not in the context of pressure from anywhere, which means finding a new wife for the husband purely from his own initiative. With the afterlife orientation, the wives seek, choose and also prepare the husband's marriage with a new wife. There are several motives that influence the idiosinkrasi of these wives, including economic, religious, traditional and political motives. In the gender context of a marriage must meet four indicators, namely access must be owned by each of husband and wife in the family, getting a fair role for what the busband and wife do, exercising the same rights and obligations especially in decision making in the family, and mutual benefits in domestic life. In practice polygamy families will have difficulty meeting the four indicators above. Because, initially, in the condition of the household is not always being together, so that it will affect access, division of family roles and responsibilities, especially in making all housebold's decisions. Even though there are several motives in polygamy initiated by the wife, it will still have an impact that is vulnerable to family conflicts.
\end{abstract}

Keywords: idiosinkrasi, finding a new wife, gender

Abstrak: Idiosinkrasi istri dalam mencarikan pasangan baru bagi suami dianggap sebagai perilaku lain dari kebanyakan istri pada umumnya. Setiap istri tidak akan mau untuk dipoligami oleh suami, akan tetapi berbeda dengan perilaku para istri dalam komunitas poligami adalah takdir, mayoritas istri pada komunitas tersebut berlomba dalam mencapai rida Allah dengan mencarikan istri baru bagi suaminya. Perilaku istri ini tidak dalam konteks tekanan dari manapun, artinya mencarikan istri baru untuk suami murni dari inisiatifnya sendiri. Dengan orientasi akhirat, para istri mencari, memilihkan dan juga mempersiapkan pernikahan suami dengan istri baru. Terdapat beberapa motif yang mempengaruhi idiosinkrasi para istri ini muncul, diantaranya yakni motif ekonomi, religious, tradisi, dan politik. Dalam konteks gender suatu pernikahan harus memenuhi empat indikator yakni akses harus dimiliki oleh masing-masing suami istri dalam keluarga, mendapat peran adil atas apa yang dilakukan suami istri,

AL-HUKAMA

The Indonesian Journal of Islamic Family Law

Volume 09, Nomor 02, Desember 2019; ISSN:2089-7480 
menjalankan hak dan kewajiban yang sama terlebih dalam pengambilan keputusan dalam keluarga, dan saling memperoleh manfaat dalam kehidupan rumah tangga. Dalam praktik keluarga poligami akan mengalami kesulitan untuk memenuhi empat indikator di atas. Karena awalnya dalam kondisi rumah tangga tidak selalu bersama sehingga akan berpengaruh pada akses, pembagian peran keluarga serta tanggung jawab, terlebih pada pengambilan segala keputusan rumah tangga. Meski terdapat beberapa motif dalam poligami yang diinisiasi oleh istri, tetap akan menimbulkan dampak yang rentan terjadi konflik keluarga.

Kata Kunci: idiosinkrasi istri, mencarikan istri baru, gender

\section{Pendahuluan}

Perempuan diciptakan istimewa oleh Allah. Sejak ia lahir, saat dewasa, bahkan ketika ia telah menjadi seorang istri. Dalam urusan rumah tangga, Allah telah mengatur sedemikian rupa agar perempuan khususnya istri terjaga hak-haknya, seperti dalam urusan poligami, terdapat batasan bahwa seorang suami tidak diperkenankan memperistri lebih dari empat, hal ini karena Allah melindungi hak istri.1 Bahkan seorang istri juga dilindungi oleh Undang-undang perkawinan tahun 1974 pasal 3 yang menyatakan bahwa pada asasnya dalam perkawinan, seorang istri harus mempunyai seorang suami.2 Begitu juga berlaku bagi seorang suami hanya boleh mempunyai seorang istri. Pemberian izin oleh pengadilan untuk suami yang berkeinginan menikah lagi maka harus ada persetujuan dari pihak-pihak yang bersangkutan, salah satunya yakni seorang istri.

Beda halnya dengan perempuan khususnya seorang istri pada komunitas poligami adalah takdir, ia mempunyai idiosinkrasi terhadap suaminya, artinya terdapat sebuah sifat yang dimiliki oleh istri yang mana ia menjadi lain dari orang kebanyakan. Pada dasarnya seorang istri tidak akan rela berbagi suami dengan perempuan manapun. Ketika ada seorang istri yang mencarikan istri baru bagi suaminya ini merupakan sebuah idiosinkrasi, juga termasuk khärij al'ádah atau di luar kebiasaan para istri pada umumnya. Para istri dalam

1 Andri Vidianto, "Fenomena Poligami pada Keluarga Miskin" (Tesis-UIN Maulana Malik Ibrahim, Malang, 2015), 23.

2 Kompilasi Hukum Islam 
komunitas poligami adalah takdir antusias dalam menggerakkan poligami dengan cara mencarikan istri baru bagi suaminya.3

Mencarikan istri baru bagi suami dilakukan dengan berbagai upaya baik melalui kajian-kajian, teman, kerabat, atau bahkan melewati media sosial. Sepertihalnya yang dilakukan oleh ibu Rezkya, ia mengupayakan agar suaminya mau untuk berpoligami dengan tujuan mencari keridaan Allah serta menggapai surga.4 Tujuan mencarikan istri baru untuk suami bermacam-macam, mulai dari bermotif ekonomi, religious, politik, tradisi, dan pragmatis. Jika dilihat dari kematangan serta kesiapan rumah tangga, keluarga para istri dalam komunitas poligami adalah takdir cenderung memiliki kesederhanaan dalam finansial maupun batinnya, karena yang menjadi acuan dalam mencarikan istri baru untuk suami yakni menggapai rida Allah, artinya mereka tidak memperhitungkan masalah ekonomi keluarga, karena para istri mempunyai keyakinan bahwa segala rezeki Allah yang telah mengaturnya dan segala yang ada di dunia hanya bersifat sementara. 5 Dalam perkembangan jaman saat ini, kebanyakan dari kaum perempuan sangat menjunjung tinggi persamaan diberbagai sektor terutama dalam hal relasi suami istri dalam keluarga, 6 akan tetapi para istri dalam komunitas poligami adalah takdir tetap berkeyakinan bahwa ketaatan pada yang maha esa tanpa syarat merupakan jalan menuju surga.

Bagi para istri tersebut, mencarikan istri baru untuk suami dipandang sebagai suatu solusi atas penyakit yang ada di masyarakat seperti dengan poligami maka suami akan terjauhkan dari zina, selingkuh dan perilaku seksual menyimpang lainya. Dengan menafsirkan ayat surat al-Nisā' ayat 2-3 mereka mempunyai dasar ideologi atas teks keagamaan tentang disyaratkannya poligami, atau bentuk sunah Rasulullah dan istri harus mengupayakan hal itu. Padahal poligami dipandang suatu hal yang negatif serta tidak dimengerti sebagai sunah, karena poligami tidak terlahir dari Islam, melainkan sebagai bentuk sejarah dalam kehidupan manusia. Dalam

3 Deny Siregar, Tuban dalam Secangkir Kopi (Jakarta: PT. Mizan Publika, 2016), 18.

4 Rezkya, Wawancara, 17 Maret 2018.

5 Ine, Wawancara, 17 Maret 2018.

6 Yusrina Sri, Bangga Jadi Perempuan (Jakarta: Kompas Gramedia, 2015), 9. 
hal ini perlu adanya persepsi antara kesetaraan dan ketidaksetaraan gender terhadap idiosinkrasi istri dalam mencarikan istri baru untuk suami.

\section{Poligami dalam Konstalasi Sejarah Masyarakat Muslim}

Dilihat dari sejarahnya, poligami sering terjadi atas kemauan suami tanpa seizin pihak istri. Masyarakat manusia telah mengenal poligami berpuluh bahkan ratusan jumlahnya, banyak wanita yang digauli. Bahkan di perjanjian lama juga menyebutkan bahwa Nabi Sulaiman mempunyai berates-ratus istri yang terdiri dari perempuan bangsawan dan gundik. Poligami tidak hanya tersebar luas dalam kawasan Arab jabiliyah saja, melainkan juga tersebar ke penjuru bangsa Sisilia dan Ibrani yang sekarang terlahir sebagai bangsa Rusia, Polandia dan Yogoslavia.7 Jika dilihat dari segi poligami Rasulullah, jelas bahwa Rasulullah mempoligami istrinya dengan alasan sosiologis dan untuk kepentingan dakwah penyebaran agama Islam. Memahami poligami Nabi saw perlu ditinjau dari segi sejarahnya, bukan yang hanya tertulis dalam ayat al-Qur'an tentang poligami, akan tetapi lebih pada memperhatikan kondisi bangsa Arab saat itu.

Konteks Arab Jahiliyah saat itu sudah membudaya poligami tanpa batas sehingga Islam datang untuk mempersempit ruang gerak laki-laki yang ingin berpoligami yakni dengan batas hanya empat orang istri saja, dalam hal ini Islam mengangkat harkat dan martabat perempuan.8 Terdapat perbedaan yang cukup signifikan atas poligami bangsa Arab pra dan pasca Islam waktu itu antara lain, ketika dahulu Islam belum masuk tidak adanya pembatasan pernikahan akan tetapi setelah Islam masuk terdapat pembatasan jumlah perkawinan, sebelum Islam datang laki-laki yang dapat menikahi lebih dari seorang perempuan berarti ia dapat dikatakan sebagai orang yang kuat, berkuasa dan sebagai kelompok yang eksklusif tetapi Islam datang mensyaratkan bahwa dalam poligami terdapat nilai yang harus dijunjung tinggi yakni keadilan dalam segala sector, pra Islam juga telah menjadi budaya yang mengakar dalam

7 Shalah Qazan, Membangun Gerakan Menuju Pembebasan Perempuan (Solo: Era Intermedia, 2001), 23.

8 Noval Maliki, "Poligami dalam Perspektif Gender (Studi terhadap Kiai di Kabupaten Cirebon)”, Jurnal Kajian Gender, Vol. 11, No. (Oktober, 2019). 124. 
masyarakat tetapi pasca Islam datang yang dibawa Rasulullah, poligami dianggap sebagai bagian dari strategi Rasulullah untuk membentuk masyarakat yang egaliter. 9

Menurut Siti Musdah Mulia menerangkan bahwa faktor sejarah poligami Rasulullah antara lain, pertama pernikahan Rasulullah secara monogami terjadi selama 28 tahun, 17 tahun dilakukan saat belum menjadi rasul serta 11 tahun setelah masa kerasulan. Kedua sewafat Khadijah dua tahun baru Rasulullah menikah kembali dengan Saudah binti Zam'ah. Ketiga Rasulullah menikah lagi dengan Saudah di kala usianya sudah lanjut, bahkan sebagian riwayat menyatakan bahwa Saudah telah manapause. Keempat usia Rasulullah pada saat melakukan poligami usianya di atas 54 tahun. Kelima pernikahan Rasulullah mulai yang ketiga hingga yang terakhir terjadi di Madinah dan berada dalam rentang waktu yang relatif pendek (antara tahun kedua sampai ketujuh hijriah), hanya lima tahun.10

Ketika ditinjau dari segi feminis, Rasulullahlah yang memperjuangkan hak-hak perempuan khususnya muslimah pertama kali. Hal ini terlihat dari cara poligami Rasulullah yang ia gunakan untuk strategi mengangkat martabat perempuan, seperti menunjukkan perempuan sälibah, mempunyai kepribagian yang tangguh, cerdas, mandiri dan selalu ada di samping Rasulullah dan mendukung beliau. Di masa sebelum Islam datang tidak ada yang memunculkan perempuan sebagai figure public dan menjadi teladan umat, namun saat Islam mulai berkembang, Rasulullah memberikan perhatian khusus terhadap kehebatan perempuan di berbagai sektor seperti, perempuan sebagai perawi hadis, penghafal al-Qur'an, mufti dan lainnya. Seperti dikisahkan salah satu istri Rasulullah yakni Ummu Salamah, beliau seorang yang mempunyai kecerdasan sosial yang tinggi, ia pernah melakukan protes pada Rasul tentang status perempuan dalam al-Qur'an yang dilihat tidak gender balance. Kisah ini sebagai awal kesadaran perempuan terhadap hak-haknya, lalu turun surat al-An-Nisā' ayat 4 . Kemudian hak waris pertama kali diterima perempuan 1:2. Pembagian seperti ini juga mengancam

9 Azwar Fajri, "Keadilan Berpoligami dalam Perspektif Psikologi", Jurnal Substansia, Vol. 13, No. 2 (Oktober, 2011), 161.

10 Siti Musdah Mulia, Ensiklopedia Muslimah Reformis (Pokok-Pokok Pemikiran untuk Reinterpretasi dan Aksi (Jakarta: Dian Rakyat, 2019), 53. 
berkurangnya hak laki-laki tidak tidak sebagaimana tradisi sebelum Islam datang.11 Demikian tidak heran jika poligami yang Rasul jalankan pasti ada hikmah yang luar biasa untuk kepentingan Islam dan pemberdayaan perempuan.

Tetapi ketika dilihat dari konteks poligami yang dilakukan keluarga modern ini terjadi pergeseran budaya, perkembangan ilmu pengetahuan dan teknologi, ikut serta dalam merubah peran, sifat dan relasi dalam keluarga, sehingga contoh ideal poligami Rasulullah tidak mungkin dilakukan, walaupun dengan mempertimbangkan keadilan.12 Untuk itu pemahaman umat Islam tentang poligami menjadi kontroversi dan tidak ada habisnya dibahas. Di satu sisi Rasulullah melakukanya dan satu sisi lainya kondisi umat Islam telah banyak mengalami perubahan setiap zamanya.

\section{Idiosinkrasi Istri antara Tradisi dan Doktrin Agama}

Idiosinkrasi istri dalam masyarakat muslim awalnya terjadi pada ibunda Siti Sarah yang menginisiasi atau mencarikan istri baru untuk suaminya yakni nabi Ibrahim. Akan tetapi perilaku yang dilakukan ibunda Siti Sarah bukan merupakan tradisi yang harus ditiru, karena perilaku tersebut dilandasi dengan alasan yang mendesak. Sejarah mencatat bahwa pernikahan antara nabi Ibrahim dengan ibunda Siti Hajar dilatarbelakangi oleh alasan personal karena pada waktu itu nabi Ibrahim dengan ibunda Siti Sarah di usia 80 tahun belum juga dikaruniai seorang anak. Artinya poligami yang dilakukan oleh nabi Ibrahim, merupakan saran dari istri pertama yakni Siti Sarah. Dahulu, ibunda Siti Sarah memberikan saran kepada Nabi Ibrahim untuk menikahi Siti Hajar yang tidak lain merupakan pembantunya sendiri. Pernikahan dari Nabi Ibrahim dan Ibunda Siti Hajar melahirkan Nabi Ismail. Setelah kelahiran Nabi Ismail, maka lahirlah anak dari Nabi Ibrahim dengan Ibunda Siti Sarah yakni Nabi Ishaq. Poligami pada keluarga Nabi Ibrahim sebenarnya menjadi tolak ukur moral bahwa seorang laki-laki ketika ingin berpoligami maka harus ada izin dari pihak istri, bukan hasil dari inisiatif sendiri dan juga

11 Muhammad Bagir al-Habsyi, Fiqih Praktis Menurut Al-Qur'an, As-Sunnah, dan Pendapat Para Ulama' (Bandung: Mizan Media Utama, 2015), 90.

12 Muhammad Mualimur Rifqi, "Keadilan dalam Poligami Perspektif Madzhab Syafi'I”, dalam Jurnal Hikmatina, Vol. 1 No. 2 ((2019) 87. 
poligami seharusnya berdasarkan pada alasan yang bersifat personal. 13

Pada kalangan beberapa istri kiai juga berupaya mencarikan istri baru untuk suaminya. Hal ini terjadi pada kiai Jombang Pondok WU, yang mana istri pertama tidak hanya memilihkan tapi juga berfungsi sebagai menyeleksi hingga menguruskan segala keperluan nikah di Kantor Urusan Agama. Istri pertama melakukan hal yang serupa hingga suaminya mempunyai empat istri. 14 Fenomena istri yang mencarikan istri baru untuk suaminya juga terjadi pada istri Abah CJ 15 yang telah mempersiapkan istri baru untuk suami selama dua tahun lalu, ia juga sebelumnya telah menawarkan 5 perempuan pada suaminya, dan pada akhirnya suami memilih pada perempuan kelahiran Jombang. Fungsi mencarikan tidak hanya berkembang pada istri nabi dan pra Islam melainkan juga berkembang pada beberapa istri para kiai.

Hakikat sifat idiosinkrasi istri ini merupakan poligami yang dilakukan suami. Segala yang berhubungan dengan poligami merupakan akar dari ajaran atau doktrin. Banyak orang yang menafsirkan surat al-Nisāa ayat 2-3 sebagai keharusan dalam berpoligami. Padahal jika dilihat dari perspektif Syahrur, istilah poligami seharusnya ada hubungannya dengan perlindungan terhadap anak yatim. Poligami baginya boleh-boleh saja, asalkan segala kebutuhan anak yatim terpenuhi dengan baik, membuat bahagia serta mensejahterakanya. Menurut pandangan Syahrur, jika seorang laki-laki boleh berpoligami asal memenuhi dua syarat yakni istri setelahnya merupakan janda yang mempunyai anak dan adanya keadilan pada anak-anak yatim tersebut. 16 Tetapi fakta di lapangan, banyak laki-laki yang poligami mengesampingkan syarat yang telah dikemukakan oleh Syahrur di atas.

13 http://www.nu.or.id/post/read/88736/belajar-dari-poligami-nabi-ibrahimdan-monogami-nabi-Zakaria. diakses pada 11 Februari 2020.

14 Nuruddin, Wawancara, 11 Februari 2020.

15 Kyai ponpes Cijeungjing, Ciamis, Jawa Barat yang melakukan poligami atas inisiatif Istri.

16 Muhammad Syahrur, Prinsip dan Dasar Hermeunetika Hukum Islam Kontemporer, terj. Shahiron Syamsudin (Yogjakarta: Elsaq, 2007), 313. 


\section{Kontruksi Sosial Idiosinkrasi Istri}

Kontruksi sosial idiosinkrasi istri terbentuk oleh beberapa faktor, motif dan tujuan yang mempengaruhi. Mulai dari faktor ekonomi, politik, religius, hingga tradisi. Dilihat dari segi ekonomi para istri yang mencarikan istri baru untuk suami mempunyai keyakinan penuh bahwa setiap orang yang lahir membawa rizkinya masing-masing. Logikanya ketika seorang istri mampu membawa orang baru dalam rumahnya, maka secara otomatis Allah akan menambah riski dalam keluarganya. Apalagi jika seorang istri tersebut mampu memberikan keturunan, dengan begitu riski keluarga akan semakin bertambah, karena menurut Abu Hurairah anak merupakan karunia. Bahkan hadirnya anak bentuk kenikmatan.17 Kebaikan akan datang dengan datangnya anak, kebaikan yang dimaksut yakni riski. Allah pun berjanji dalam firmannya bahwa setiap kelahiran anak akan membawa rezekinya. Berdasarkan surat al-An'am ayat 151 yang bermaksut bahwa dilarangnya membunuh anak-anak yang lahir karena takut miskin, Allah telah berjanji untuk memberi rezeki kepada orang tua dan kepada mereka. Ayat di atas menjadi pijakan bagi istri yang mencarikan istri baru untuk suaminya, tidak pernah merasa risau atau khawatir akan segala macam tuntutan hidup, lebih-lebih berupa rezeki. Dengan datangnya istri baru juga dapat menambah semangat suami dalam mencari nafkah, karena baginya suami akan mengerti bahwa akan banyak yang perlu dipenuhi kebutuhan hidup dalam keluarganya. 18

Ditinjau dari segi politik, yang mengkonstruk idiosinkrasi istri yakni sebuah legalitas hadis riwayat Abu Daud: 2052, disahihkan Albani dalam Sahīh Jāmi': 5251 yang mengungkapkan bahwa Rasulullah memerintahkan untuk menikahi wanita yang pecinta serta subur.19 Dengan begitu Rasul akan bangga dengan banyaknya

17 Majalah Assunnah, "Anak Itu Titipan dan Pembawa Rizki dalam Rumah Tangga", terbit pada 05/Tahun XIII/1430/2009 M (Solo: Lajnah Istiqomah, 2009), 15.

18 Nur Amalia, "Indikasi Sosiologis Terjadinya Poligami di Kalangan Masyarakat Bogor", Jurnal Ilmu Syariah, Vol. 1, No. 12013 ((2013), 127.

19 M. Quraish Shihab, Pengantin Al-Qur'an: Kalung Permata Buat Anak-anakku (Tangerang: Lentera Hati, 2007), 82. 
umat yang dilahirkan. Salah satu upaya agar mempunyai keturunan yang banyak, maka para istri melakukan gerakan poligami dengan menginisiasi pencarian "adik" madu.20 Hal ini juga dilakukan untuk memperbanyak dan memperkokoh dawlah Islämìyah. Tidak hanya itu, berkembangnya Islam menjadi besar di suatu negara salah satunya dengan mencarikan istri baru untuk suami. Hadis di atas telah melegitimasi pola pikir bahwa Rasulullah akan bangga dengan banyaknya pengikut di hari kiamat nanti. Dapat dikatakan suatu peradaban yang maju ketika moyoritas Islam telah mendunia, dan yang berhak menjadi üli al-amr pastinya yang beragama Islam. Hal ini dikuatkan oleh perkataan Mauja bahwa jika mayoritas beragama Islam dan pemimpinnya juga berasal dari Islam, maka kemungkinan besar sistem negara akan bisa dirubah menjadi hukum sesuai syariat Islam.

Kemuliaan suatu perempuan dapat diukur dengan mencarikan istri baru untuk suami,21 karena menimbang dari berbagai aspek tentang Islam di masa depan. Artinya dengan banyaknya ibu yang melahirkan anak, maka pendidikan secara Islami akan selalu diterapkan sehingga ketika anak telah menjadi dewasa akan selalu komitmen dengan ajaran Islam dan berpegang pada sunah. Tidak hanya itu, melewati pintu seperti ini juga akan membuka wawasan bahwa seorang yang beragama Islam wajib mewujudkan kehidupan Islami serta pengaplikasian dalam kehidupan sehari-hari melalui dakwah. Sehingga kejayaan umat Islam akan segera terwujudkan. Dengan banyaknya pengikut Islam maka akan semakin mudah untuk membentuk negara khiläfah Islämìyah sebagai pusat peradaban umat muslim.22

Tradisi juga mempengaruhi idiosinkrasi para istri dalam mencarikan istri baru bagi suami. Berpacu pada kisah ibunda Siti Sarah yang mencarikan istri baru untuk Nabi Ibrahim, seolah dari tradisi tersebut para istri memiliki motivasi tersendiri. Tidak hanya itu, beberapa istri para wali Allah dan kiai juga mempraktikkan hal

20 Adik madu yang dimaksut dalam penelitian ini yaitu istri kedua, ketiga dan keempat.

21 Mauja N, Wawancara, 18 Juli 2018.

22 Muhammadin, "Relevansi Sistem Khilafah HTI dengan Sistem Negara Islam Modern”, Jurnal Intizar, Vol. 22, No. 2 (2016), 135. 
yang serupa. Hal ini terjadi pada istri dari kiai Jombang ponpes WU, istri abah Jc, istri dari kiai Hayat al-Makki Pare Kediri, istri kiai Dahlan Nganjuk dan istri kiai Ageng Besari Ponorogo. Meneladani para pendahulu merupakan suatu yang baik, karena pada hakikatnya mereka mempunyai alasan yang tepat sebelum bertindak. Banyak manfaat yang dapat diambil ketika seorang istri mencarikan istri baru bagi suami yakni salah satunya menghindarkan suami dari perbuatan zina serta perbuatan menyimpang lainnya.23

Ditinjau dari sisi religiositas, maka segalannya akan dikembalikan pada Allah termasuk urusan hati. Karena yang berhak membolakbalikkan hati setiap manusia adalah Allah. Idiosinkrasi istri ini disebabkan karena bentuk kecintaan kepada Allah sangat kuat. Bahkan ketika Allah mengambil suaminya untuk orang lain maka ia hanya bisa pasrah kepada-Nya. Seperti halnya yang dikatakan oleh Riskiyah bahwa di dunia ini yang berhak dicintai adalah Allah bukan suami, karena semua yang ada di dunia merupakan miliki Allah dan hanya pada Allah lah semua diserahkan.24 Dengan mencarikan istri baru untuk suami maka dapat meyakinkan bahwa perbuatannya itu semata-mata hanya tidak mau melebihi cintanya pada Allah. Seorang istri pun tidak mempunyai otoritas lebih pada suaminya, karena semua otoritas suami hanya pada Allah. Para istri yang mencarikan istri baru untuk suaminya pun merasa bahagia karena tidak mudah dan tidak semua perempuan mampu untuk melakukan perbuatan tersebut. Dalam mencarikan istri baru untuk suami maka secara tidak langsung istri telah menjalankan tauhid pada Allah dalam urusan kecintaan terhadap-Nya.

Perilaku idiosinkrasi istri sah-sah saja, karena Islam pun juga membolehkan laki-laki untuk berpoligami. Idiosinkrasi para istri juga dipengaruhi oleh jaminan Allah atas surga bagi orang yang taat pada suami. Ketika para istri itu mencarikan istri baru bagi suaminya berarti istri tersebut sama saja dengan menjemput surga untuk diri sendiri. Hal ini termaktub pada hadis dengan maksud para perempuan, istri, akan memasuki surga dari pintu manapun yang dikehendaki asal ia mampu taat pada suami. Setiap suami

23 Maryam J., Wawancara, 22 April 2019.

24 Riskiyah, Wawancara, 17 September 2018. 
mempunyai hak poligami dan sebelum suami menagih haknya alangkah baiknya istri yang menawarkan. Hal ini telah menjadi legitimasi pola pikir para istri sehingga terbentuknya idiosinkrasi.

\section{Teori dan Konsep Gender}

Permulaan diperkenalkannya sebutan gender oleh ilmuwan sosial bertujuan menerangkan bedanya antara perempuan dan lakilaki yang sifatnya melekat atas ciptaan Allah dan bersifat buatan budaya yang dipahami dan dipertontonkan sejak kecil. Pada umumnya, gender telah menumbuhkan perbedaan tugas, hak dan kewajiban, fungsi bahkan tempat di mana manusia beraktivitas. Term gender dapat dimaknai sebagai perbedaan tugas, fungsi, status dan pemahaman kewajiban dan hak pada laki-laki dan perempuan sebagai produk dari tatanan (kontruksi) sosial budaya yang telah melegitimasi melewati proses diseminasi dari satu keturunan ke keturunan berikutnya.25 Definisi gender banyak dikemukakan oleh para ahli, akan tetapi menurut kamus besar Bahasa Indonesia gender merupakan beraneka macam bentuk fisik dan psikologi yang membedakan maskulinitas dan feminitas. 26

Gender sebenarnya telah ada sejak sepuluh tahun terakhir, ia masuk dalam perbendaharaan setiap diskusi dan karya tulis atas konstruksi sosial dan pembangunan dalam "dunia ketiga". Begitu pula di Indonesia, mayoritas kalangan organisasi nonpemerintah membicarakan masalah perkembangan masyarakat maupun pembangunan dengan memakai gender. Dilihat dari segi bahasa, gender dalam bahasa Indonesia diambil dari bahasa Inggris. Sedangkan dalam kamus, tidak ada keterangan jelas tentang pemahaman antara sex dan gender. Maka dari itu, untuk pemahaman tentang gender tidak menuntut kemungkinan harus paham juga tentang perbedaan antara gender dan sex (jenis kelamin).27

Perubahan tempat, waktu dan zaman dapat merubahnya ciri dari sifat-sifat daerah. Contohnya dahulu kala perempuan lebih kuat

25 Herien Puspitawati, Gender dan Keluarga Konsep dan Realita di Indonesia (Bogor, Penerbit IPB Press: 2017), 60.

26 Kamus Besar Bahasa Indonesia (KBBI), online, diakses pada 29 Januari 2020. 27 Mansour Fakih, Analisis gender dan Transformasi Sosial (Jogjakarta, Pustaka Pelajar: 2013), 8 . 
daripada laki-laki di beberapa suku, sedangkan di zaman yang lain dan pada tempat yang lain pula malah sebaliknya. Perubahan dapat dialami dari lingkup terkecil hingga pada masyarakat. Pada suku tertentu, perempuan pedesaan akan lebih kuat dari pada dari pada kaum laki-laki, hal ini dapat berubah sesuai tempat, perbedaan kelas dan perpindahan waktu ke waktu. Hal seperti ini dikenal dengan konsep gender. Realita yang ada melegitimasi perempuan akan mengurus keluarga, menjaga dan mendidik anak, serta mengelola dan membersihkan rumah atau semua hal yang bersifat domestik. Hal itu semua merupakan tanggung jawab seorang istri. Ini jelas adanya kontruksi kultural masyarakat tertentu. Semua yang berurusan dengan hal di atas sering orang menyebutnya sebagai kodrat perempuan, padahal itu sesunguhnya merupakan gender.28

Dalam gender tidak harus ada perbedaan yang berkepanjangan apalagi hingga menjadi masalah. Realita yang ada, justru gender menjadi masalah karena adanya ketidakadilan. Ketidakadilan gender merupakan sebuah pola yang mana laki-laki maupun perempuan dijadikan korban atas pola itu sendiri. Maka dari itu, untuk mengetahui ketidakadilan di dalamnya, terdapat sebuah konsep ketidakadilan gender antara lain:

1. Gender dan marginalisasi perempuan

Kemiskinan dapat disebabkan oleh marginalisasi yang dilakukan. Realitanya mayoritas kalangan laki-laki dan perempuan dalam masyarakat maupun Negara turut ditimpa yang dikarenakan beberapa kejadian, contohnya penggusuran, bencana alam dan lain-lainnya. Pada siklus tempat bekerja, perempuan seringkali termaginalkan oleh berbagai pihak. Tidak hanya itu perempuan juga mendapat perlakuan yang serupa pada tingkat keluarga, masyarakat bahkan Negara. Biasanya marginalisasi semacam ini berbentuk diskriminasi.29 Bahkan tafsir keagamaan yang kurang kompeten pun turut andil dalam memperkuat terjadinya marginalisasi. Contohnya tidak sedikit perempuan tidak mendapatkan hak warisnya dalam berbagai suku tertentu. Contoh marginalisai dalam keluarga yakni suami

28 Ibid., 10.

29 Anisa Wihayati, “Analisis Framing Pandangan Poligami dalam Acara cerita hati kompas TV episode 183” (Tesis--UIN Sunan Ampel Surabaya, 2018), 68. 
menghendaki agar istrinya tidak bekerja karena mengurus anak dan itu tidak dimusyawarahkan terlebih dahulu.

2. Gender dan subordinasi

Subordinasi terhadap perempuan dapat ditimbulkan oleh pandangan gender. Umumnya masyarakat berpandangan bahwa perempuan lebih dominan dengan emosionalnya dan mengesampingkan rasionalitasnya, sehingga sering kali ada anggapan jika perempuan tidak layak untuk memimpin. Maka dari itu, wadah yang tidak penting sering didominasi oleh perempuan.Subordinasi dialami pada siklus tempat satu dan waktu satu pada yang lain. Masyarakat Jawa, menganggap perempuan itu akhirnya akan di dapur meski ia sekolah tinggi, maka anggapan semacam itu akan melahirkan paradigma perempuan tidak harus sekolah tinggi. Bahkan pemerintah pernah mempunyai peraturan bahwa ketika suami tidak dekat dengan rumah atau kerja jauh maka segala tindakan akan diputuskan sendiri.30 Sedangkan bagi istri yang hendak pergi kemanapun harus degan izin suami. Dalam urusan rumah tangga masih sering terdengar jika keuangan keluarga sangat terbatas dan harus mengambil keputusan untuk menyekolahkan anakanaknya. Maka anak laki-laki akan mendapatkan prioritas utama. Praktik seperti itu sesungguhnya berangkat dari kesadaran gender yang tidak adil.

3. Gender dan streotipe

Pada umumnya pelabelan terhadap masyarakat tertentu biasa disebut streotipe. Celakanya streotipe selalu merugikan dan menimbulkan ketidakadilan. Tidak sedikit ketidakadilan dialami jenis kelamin tertentu. Pada umumnya perempuan sering mendapatkan penandaan (streotipe) yang tertuju kepadanya, semisal, kebersolekan perempuan dianggap sebagai pemancing laki-laki untuk mendekat, maka tidak heran ketika ada kekerasan atau tindakan yang kurang patut maka akan dikaitkan dengan streotipe ini. Bahkan ketika terdapat pemerkosaan terhadap perempuan, masyarakat lebih condong untuk menyalahkan

30 Ibid., 63. 
perempuan.31 Begitu juga anggapan bahwa peran utama para istri adalah yang selalu siap sedia melayani suami. Streotipe semacam ini akan menyebabkan ketika pendidikan kaum perempuan dinomorsekiankan.

4. Gender dan kekerasan

Kekerasan (violence) merupakan perilaku penyerangan pada fisik atau psikis seseorang. Kekerasan yang terjadi disebabkan dari berbagai sumber, tetapi terdapat anggapan gender yang dapat menyerang jenis kelamin tertentu. Hakikatrnya, kekerasan gender disebabkan oleh adanya penindasan pada seseorang yang power less. Terdapat kategori yang dapat diindikasikan sebagai kejahatan gender, yakni: pertama, bentuk pemerkosaan terhadap perempuan, termasuk perkosaan dalam perkawinan. Pemerkosaan dalam perkawinan yakni adanya paksaan hubungan suami istri tanpa adanya kerelaan dari salah satu pihak. Kedua, tindakan pemukulan dan serangan fisik yang terjadi dalam rumah tangga (domestic violence).32 Termasuk tindak kekerasan dalam bentuk penyiksaan terhadap anak-anak. Ketiga, bentuk kekerasan terhadap alat kelamin, sepertihalnya penyunatan terhadap perempuan. Keempat, kekerasan dalam bentuk pelacuran. Pelacuran adalah bentuk kekerasan terhadap perempuan yang diselenggarakan oleh suatu mekanisme ekonomi yang merugikan kaum perempuan. Kelima, kekerasan dalam bentuk pemaksaan sterilisasi dalam keluarga berencana. Ketujuh, jenis kekerasan terselubung, artinya menyentuh bagian dari perempuan tanpa adanya kerelaan atau izin dari pemilik tubuh tersebut. Biasanya jenis kekerasan begini terjadi di sekitar tempat kerja. Kedelapan, tindakan kejahatan terhadap perempuan yang paling umum dilakukan di masyarakat yakni yang dikenal dengan pelecehan seksual.

5. Gender dan beban kerja

Perempuan dianggap tidak dapat menjadi kepala rumah tangga karena ia memiliki sifat yang lemah lembut dan rajin. Sehingga seorang perempuan harus bertanggung jawab atas

31 Ibid., 65.

32 Ibid., 68. 
segala pekerjaan domestik, mulai dari memasak, membersihkan rumah, mengepel, mencuci hingga mengurus anak.33 Pada kalangan keluarga miskin beban seperti ini biasanya ia pikul sendiri dan tidak ada yang membantu sehingga para istri mempunyai beban ganda. Dalam urusan domestik biasanya istrilah yang selalu melakukan sehingga seringkali masyarakat berpandangan bahwa semua jenis pekerjaan domestik merupakan jenis pekerjaan yang dinilai rendah dan lebih tidak produktif dibanding pekerjaan luar rumah seperti halnya laki-laki. Sedangkan dalam masyarakat menengah ke atas pekerjaan domestik seperti itu dialihkan pada pembantu rumah tangga. Sebenarnya, ia juga telah menjadi korban bias gender di masyarakat.

Dalam mengadakan kesetaraan dan keadilan gender pada keluarga maka akan ada tahapan yakni, pertama akses, yang dapat dipahami sebagai ukuran atas dipergunakannya sumber daya untuk seluruhnya berpartisipasi aktif baik secara sosial, ekonomi maupun politik kaitannya dengan masyarakat dalam akses kesumber daya, pelayanan, tenaga kerja dan pekerjaan, informasi dan manfaat.34 Seperti halnya, memberikan pelayanan atau kesempatan sekolah untuk perempuan ataupun laki-laki sesuai bakat dan minatnya.35 Kedua partisipasi, dalam keluarga harus ikut andil dalam segala urusan. Artinya di musyawarahkan dengan melibatkan suami istri kalau perlu juga anak laki-laki maupun perempuan. Ketiga control, istri dan suami mempunyai hak yang sama yakni mengontrol segala yang berhubungan dengan keluarga. Suami istri bisa mempunyai properti atas nama keluarga. Keempat manfaat, semua macam kegiatan seharusnya memiliki manfaat yang dapat dirasakan oleh semua anggota keluarga.

\section{Idiosinkrasi Istri dalam Gender}

Idiosinkrasi istri terbentuk melalui beberapa faktor, motif serta tujuan, mulai dari faktor ekonomi, politik, tradisi, serta religiositas. Secara teoriretik ayat agama telah melegitimasi pola fikir para istri

33 Ibid., 69.

34 Ibid., 70.

35 Ibid., 71. 
dengan mengaplikasikan dalam kehidupannya mempunyai dampak yang sangat berbeda. Artinya akan timbul relasi yang tidak baik antara suami istri dengan istri yang lain, anak istri satu dengan anak istri yang lain, atau bahkan keluarga dengan sosial masyarakat. Maka dari itu, dalam idiosinkrasi semacam ini perlu adanya analisis gender, karena gender masih dapat digunakan untuk masa kini serta sudah menjadi keharusan memasukkan dalam membahas konsep dan ruang lingkup gender dalam kehidupan keluarga.36 Maka dari itu konsep keadilan dan kesetaraan gender dapat mempengaruhi terwujudnya keluarga yang diharapkan. Tidak mungkin kalanya seseorang menolak konsep gender dalam rumah tangga, karena dalam kegitan keseharian terdapat peran gender di dalamnya. Jika diibaratkan gender itu seperti halnya pisau yang bisa pakai untuk menghilangkan nyawa seseorang atau menghilangkan nyawanya sendiri bahkan bisa dibuat alat untuk membantu sesama.37

Dari segi politik, para istri menginginkan untuk membangun kejayaan Islam dari poligami, karena dengan jalan poligami maka akan terlahir pemuda-pemuda Islam. Hal seperti itu justru berbanding terbalik dengan realitas pernikahan, bahwa pernikahan dengan istri kedua hingga istri keempat akan dilakukan pernikahan di bawah tangan dan tidak dapat dicatatkan pada Kantor Urusan Agama (KUA). Pernikahan yang tidak dicatatkan berarti tidak sah di mata Negara dan tidak mendapat perlindungan hukum, hal ini akan berdampak buruk pada perempuan ketika dalam rumah tangga terdapat konflik yang berujung perceraian.38

Dari segi faktor ekonomi, Allah akan selalu memenuhi segala apa yang dibutuhkan, akan tetapi dengan kesungguhan suami dalam mencari rezeki. Untuk istri yang masih bergantung ekonomi pada suami, walaupun suami telah berbuat adil terhadap istri-istrinya akan ada kerelaan dari salah satu istri, artinya ada istri yang dirasa harus dipenuhi secara berlebihan. Kenyataannya, terdapat beberapa suami

36 Isnatin Ulfa, "Transformasi Kesadaran Gender Perempuan dan Implikasinya terhadap Tingginya Gugat Cerai di Ponorogo", Jurnal Kodifikasia, Vol. 5, No. 1 (2011), 67.

37 Ibid., 43.

38 Amir Syarifuddin, Hukum Perkawinan Islam di Indonesia (Jakarta: Kencana, 2009), 56-57. 
yang lebih mementingkan istri muda dahulu dan menelantarkan anak-anak serta istri pertamanya. Hal ini akan berakibat pada istri pertama yang tidak memiliki pekerjaan akan kesulitan dalam mengurus anak dan rumah tangganya.

Pernikahan yang berkesetaraan dan berkeadilan gender harus memenuhi empat indikator yakni akses harus dimiliki oleh masingmasing suami istri dalam rumah tangga, mendapat tugas yang tidak tumpang tindih, menerima hak, kewajiban dan tanggung jawab yang sama terlebih dalam mengambil keputusan dalam keluarga serta saling memperoleh manfaat dalam kehidupan rumah tangga.39 Dalam praktik keluarga poligami akan mengalami kesulitan untuk memenuhi empat indikator di atas. Awalnya dalam kondisi rumah tangga tidak selalu bersama sehingga akan berpengaruh pada akses, pembagian tugas rumah tangga serta tanggung jawab, terlebih dalam mengambil keputusan dan menerima manfaat dalam aktivitas keluarga. Tidak adanya kesetaraan di dalam keluarga seperti ini, maka akan terjadi diskriminasi gender dalam keluarga yang biasanya terjadi pada seorang istri.

Jika dilihat dari stereotype, para istri dianggap lemah oleh sebagian masyarakat karena keterlaluannya dalam taat pada suami, sehingga ada yang menafsirkan bahwa salah satu bentuk ketaatannya yakni dengan mencarikan istri baru untuk suami. Ada sebagian persepsi pada kalangan perempuan atau istri yang mencarikan istri baru bagi suami, beranggapan bahwa suatu perilaku mencarikan istri baru untuk suami merupakan hal yang wajar, padahal dibalik perilaku tersebut dianggap oleh sebagian perempuan pada umumnya sebagai perilaku tidak pantas dengan hak-hak yang dimiliki istri yang alasanya bahwa perilaku tersebut bukan kodrat istri dengan segala keterbatasannya memang tidak layak berperilaku seperti itu, hanya demi menggapai surga. Ayat surat al-Nisā ayat 2-3 telah melegitimasi pola pikir istri sehingga ia memiliki idiosinkrasi dalam mencarikan istri baru bagi suaminya.40

Istri sering kali terletak pada subordinasi dalam rumah tangga. Istri seharusnya merupakan bagian dari suami di berbagai bidang

39 Ibid., 215.

40 Nurcholish Madjid, Islam Doktrin dan Peradaban (Jakarta: Paramadina, 1998), 15. 
mulai peran, tanggung jawab sampai seks.41 Akan tetapi ada beberapa istri yang power less serta menjadikan dirinya di bawah naungan suami, sangat besar ketergantungan istri pada suami secara psikologisnya. Karenanya marjinalisasi dalam keluarga sering muncul akibat subordinasi perempuan sebagai istri yang dipoligami apalagi sampai sebagai inisiator untuk suaminya poligami. Bentuk yang tampak akibat marjinalisasi dalam rumah tangga yakni adanya sisi ketidakadilan dalam mengatur ekonomi dan pemanfaatan sumber daya dalam rumah tangga. Contohnya, pada mulanya nafkah dari suami hanya teruntuk hanya satu istri akan tetapi ketika adanya istri baru, suami harus berlaku adil dalam pembagiannya. Kadangkala, para istri yang tidak mendapatkan nafkah yang layak atau tidak seimbang antara nafkah dengan kebutuhan rumah tangga, sehingga menimbulkan beban ganda yang tidak proporsional berupa mengurus rumah tangga dan juga mencari nafkah.42

Berdasarkan tradisi Nabi dan kiai, pencarian istri baru bagi suami memiliki tujuan dan tidak untuk dijadikan suri tauladan oleh semua kalangan. Jika mengacu pada ibunda Siti Sarah yang mencarikan istri baru berupa Ibunda Siti Hajar untuk Nabi Ibrahim itu ada tujuan personal yakni untuk mendapatkan keturunan karena sudah lama pernikahan nabi Ibrahim dengan Siti Sarah tidak dikaruniai putra. Sedangkan jika mengacu pada kiai, maka jelas idiosinkrasi istri beliau untuk tujuan umat yakni untuk membantu dakwah beliau. Akan tetapi ketika idiosinkrasi ini dilakukan oleh seorang perempuan pada umumnya akan lebih baik melakukan pernikahan yang monogami, karena poligami rentan timbul konflik dalam keluarga. Istri dalam mencarikan istri baru bagi suami secara suka rela dan bertujuan melestarikan perilaku para pendahulu.

Setiap orang menginginkan keluarga yang harmonis antara keduanya. Fungsi keluarga yakni terlindunginya masing keluarga dari ancaman luar keluarga.43 Karena keluarga merupakan tempat yang paling aman untuk berlindung, tanpa adanya rintangan psikologis

41 Anis Miswoni, "Streotipe Kesetaraan Gender terhadap budaya pernikahan dini pada masyarakat Madura", dalam Jurnal program studi Ilmu Komunikasi, Vol.9 No. 1 (April, 2016), 94.

42 Asghar Ali Engineer, Pembebasan Perempuan (Yogyakarta: LKiS, 2003), 34.

43 RA. Kartini, Habis Gelap Terbitlah Terang (Jakarta: Balai Pustaka, 2009), 76. 
yang akan berdampak pada terbentuknya rumah tangga yang diidamkan.44 Pada keluarga poligami terkhusus bagi istri yang mencarikan istri baru untuk suaminya kadangkala suami merasa terpaksa menerimanya, dan istri memaksakan kehendak yang nantinya akan ada dampak buruk pada keluarga. pada awalnya memang suami bisa adil dalam hal nafkah, akan tetapi istri tidak bisa memungkiri bahwa ada sedikit mengalami hambatan psikologis, meskipun posisi istri sebagai yang mencarikan. Rasa ketidaknyamanan, rasa cemburu dan lain sebagainya akan muncul tiba-tiba seiring suami berusaha memperlakukan seadil-adilnya dalam rumah tangga, rasa yang seperti itu ketika bermunculan terus menerus akan menimbulkan masalah dalam rumah tangga. Di antara istri-istri akan saling cemburu dan berebut kasih sayang suami, hal ini posisi istri-istri semakin kecil, ketergantungan dan mudah terhegemoni. Di lain pihak suami semakin berpeluang untuk memperkuat kekuasaan yang sangat rentan melakukan tindakan kekerasan di dalam keluarga.

Pernikahan merupakan ikatan suci dan sakral, ketika seseorang suami memilih untuk berpoligami atau menerima dicarikan istri baru, maka suami sama saja dengan menciderai komitmen yang mulanya dibangun berdua. Ditinjau dari segi gender, idiosinkrasi istri dalam mencarikan istri baru bagi suaminya merupaka upaya yang menjauhkan ia dari perwujudan keluarga yang sakinah, mawaddah, dan rabmah, serta sulitnya tercipta keluarga yang sehat lahir maupun batin. Bahkan Rasulullah telah memberikan peringatan bagi pelaku poligami akan memiliki konsekuensi moral yang berat yakni siapapun yang memiliki istri lebih dari satu dan tidak dapat berbuat adil maka pada hari kiamat ia akan dibangkitkan dengan salah satu bahunya patah.45

\section{Penutup}

Pernikahan yang berkesetaraan dan berkeadilan gender harus memenuhi empat indikator yakni akses harus dimiliki oleh masingmasing suami istri dalam keluarga, mendapat tugas yang adil antar

44 Ibid., 216.

45 Didi Sumardi, "Poligami Perspektif Keadilan Gender”, Journal 'Adliyah, Vol. 9, No. 1 (Januari-Juni, 2015), 187. 
suami istri, mempunyai hak dan kewajiban yang sama terlebih dalam pengambilan keputusan dalam keluarga dan saling memperoleh manfaat dalam kehidupan rumah tangga. Dalam praktik keluarga poligami akan mengalami kesulitan untuk memenuhi empat indikator di atas. Karena awalnya dalam kondisi rumah tangga tidak selalu bersama sehingga akan berpengaruh pada keempat indikator yang harus terpenuhi dalam keluarga. Tidak adanya kesetaraan di dalam keluarga seperti ini, akan menimbulkan diskriminasi gender yang biasanya terjadi pada istri. Jika dilihat dari stereotype, para istri dianggap lemah oleh sebagian masyarakat karena keterlaluannya dalam taat pada suami, sehingga ada yang menafsirkan bahwa salah satu bentuk ketaatannya yakni dengan mencarikan istri baru untuk suami. Istri sering kali terletak pada subordinasi dalam rumah tangga, istri seharusnya merupakan bagian dari suami di berbagai bidang mulai peran, tanggung jawab samapi seks. Akan tetapi ada beberapa istri berpower less serta menjadikan dirinya di bawah naungan suami, sangat besar ketergantungan istri pada suami secara psikologis.

\section{Daftar Pustaka}

Amir Syarifuddin. Hukum Perkawinan Islam di Indonesia. Jakarta: Kencana, 2009.

Andri Vidianto. "Fenomena Poligami pada Keluarga Miskin". Tesis_-UIN Maulana Malik Ibrahim, Malang, 2015.

Anis Miswoni. "Streotipe Kesetaraan Gender terhadap budaya pernikahan dini pada masyarakat Madura", dalam Jurnal program studi Ilmu Komunikasi. Vol.9, No. 1, April, 2016.

Anisa Wihayati. "Analisis Framing Pandangan Poligami dalam Acara Cerita Hati Kompas TV episode 183". Tesis-UIN Sunan Ampel Surabaya, 2018.

Asghar Ali Engineer. Pembebasan Perempuan. Yogyakarta: LKiS, 2003. Assunnah, Majalah. Anak Itu Titipan dan Pembawa Rizki dalam Rumah Tangga, terbit pada 05/Tahun XIII/1430/2009 M. Solo: Lajnah Istiqomah, 2009.

Azwar Fajri. "Keadilan Berpoligami dalam Perspektif Psikologi". Jurnal Substansia, Vol. 13, No. 2, Oktober, 2011.

Deny Siregar. Tuban dalam Secangkir Kopi. Jakarta: PT. Mizan Publika, 2016. 
Didi Sumardi. "Poligami Perspektif Keadilan Gender", Journal 'Adliyah, Vol. 9, No. 1, Januari-Juni, 2015.

Herien Puspitawati. Gender dan Keluarga Konsep dan Realita di Indonesia. Bogor: Penerbit IPB Press: 2017.

http://www.nu.or.id/post/read/88736/belajar-dari-poligami-nabiibrahim-dan-monogami-nabi-Zakaria. diakses pada 11 Februari 2020.

Ine, Wawancara, 17 Maret 2018.

Isnatin Ulfa. "Transformasi Kesadaran Gender Perempuan dan Implikasinya terhadap Tingginya Gugat Cerai di Ponorogo". Jurnal Kodifikasia. Vol. 5, No. 1, 2011.

Kamus Besar Bahasa Indonesia (KBBI), online, diakses pada 29 Januari 2020.

M. Quraish Shihab. Pengantin Al-Qur'an: Kalung Permata Buat Anakanakku. Tangerang: Lentera Hati, 2007.

Mansour Fakih. Analisis gender dan Transformasi Sosial. Jogjakarta, Pustaka Pelajar: 2013.

Maryam J.. Wawancara, 22 April 2019.

Mauja N.. Wawancara, 18 Juli 2018.

Muhammad Bagir Habsyi (al),. Fiqih Praktis Menurut Al-Qur'an, AsSunnah, dan Pendapat Para Ulama'. Bandung: Mizan Media Utama, 2015.

Muhammad Mualimur Rifqi. "Keadilan dalam Poligami Perspektif Madzhab Syafi'I”, dalam Jurnal Hikmatina, Vol. 1, No. 2, 2019.

Muhammadin. "Relevansi Sistem Khilafah HTI dengan Sistem Negara Islam Modern", dalam Jurnal Intizar, Vol. 22, No. 2, 2016.

Noval Maliki. "Poligami dalam Perspektif Gender (Studi terhadap Kiai di Kabupaten Cirebon)". Jurnal Kajian Gender, Vol. 11, No. 1, Oktober 2019.

Nur Amalia. "Indikasi Sosiologis terjadinya poligami di kalangan masyarakat Bogor", dalam Jurnal Ilmu Syariah, Vol. 1, No. 1, 2013.

Nurcholish Madjid. Islam Doktrin dan Peradaban. Jakarta: Paramadina, 1998.

Nuruddin, Wawancara, 11 Februari 2020. 
Hawa' Hidayatul Hikmiyah: Idiosinkrasi Istri.....

RA. Kartini. Habis Gelap Terbitlah Terang. Jakarta: Balai Pustaka, 2009.

Rezkya, Wawancara, 17 Maret 2018.

Riskiyah, Wawancara, 17 September 2018.

Shalah Qazan. Membangun Gerakan Menuju Pembebasan Perempuan. Solo: Era Intermedia, 2001.

Siti Musdah Mulia. Ensiklopedia Muslimah Reformis Pokok-Pokok Pemikiran untuk Reinterpretasi dan Aksi. Jakarta: Dian Rakyat, 2019.

Syahrur, Muhammad. Prinsip dan Dasar Hermeunetika Hukum Islam Kontemporer, terj. Shahiron Syamsudin. Yogjakarta: Elsaq, 2007.

Yusrina Sri. Bangga Jadi Perempuan. Jakarta: Kompas Gramedia, 2015. 